Tropical Journal of Pharmaceutical Research March 2021; 20 (3): 467-473

ISSN: $1596-5996$ (print); 1596-9827 (electronic)

(C) Pharmacotherapy Group, Faculty of Pharmacy, University of Benin, Benin City, 300001 Nigeria.

Available online at http://www.tjpr.org

Original Research Article

http://dx.doi.org/10.4314/tjpr.v20i3.4

\title{
Paeonol enhances TRAIL-induced apoptosis of human lung cancer cells by upregulating death receptors- 4 and 5 via ROS-JNK/ERK-CHOP signaling
}

\author{
Yanqing Fan', Xiaoyan Chen², Guizhi Zhang ${ }^{3 *}$ \\ ${ }^{1}$ The Third Affiliated Hospital of Kunming Medical University, Kunming 650106, 2Department of Western Medicine Education, \\ Shandong College of Traditional Chinese Medicine, Yantai 264199, ${ }^{3}$ College of Pharmacy, Hubei University of Chinese \\ Medicine, Wuhan, Hubei 43 0065, China
}

*For correspondence: Email: edsklt@163.com

Sent for review: 12 February 2020

Revised accepted: 19 February 2021

\begin{abstract}
Purpose: To study the anti-proliferative potential of paeonol against lung cancer cells, and investigate its mechanism of action.

Methods: Cell viability after paeonol treatment was determined with 3-(4,5-dimethylthiazol-2yl)2,5diphenyltetrazolium bromide (MTT) assay, while paeonol- and TRAIL-mediated apoptosis was assayed using flow cytometry. Western blotting was used to assay the protein expression levels of phosphorylated JNK and ERK1/2, as well as protein expressions of pro-apoptotic factors/death receptors. 2', 7'-Dichlorodihydrofluorescein diacetate (H2DCFDA) staining and flow cytometry were used to monitor paeonol-induced reactive oxygen species (ROS) in the cells.

Results: Paeonol treatment markedly reduced the proliferations of H1975 and BGC823 cells $(p<0.05)$. In H1975 and BGC823 cells, paeonol/TRAIL combination increased apoptosis to 88.43 and $87.21 \%$, respectively $(p<0.05)$. The levels of death receptor 4 (DR4) and death receptor 5 (DR5) were increased significantly by paeonol, relative to the control $(p<0.05)$. Paeonol also reduced the levels of decoy receptor-1 (DcR1) and decoy receptor-2 (DcR2), and increased the expression of CHOP $(p<$ 0.05). The protein expression levels of survivin, Bcl-2, cFLIP and Bcl-xL were decreased, while protein levels of caspase3, caspase-8 and caspase-9 were upregulated by paeonol. Moreover, paeonol significantly upregulated p-ERK and p-JNK in H1975 and BGC823 cells, and also increased ROS levels, when compared to control $(p<0.05)$.

Conclusion: Paeonol exerts anti-proliferative potential on lung cancer cells through upregulation of death receptors, activation of JNKJERK-CHOP pathway and generation of ROS. Therefore, paeonol has a therapeutic potential for the management of lung cancer.
\end{abstract}

Keywords: Paeonol, Proliferation, Reactive oxygen species, Apoptosis, Tumour necrosis factor

This is an Open Access article that uses a fund-ing model which does not charge readers or their institutions for access and distributed under the terms of the Creative Commons Attribution License (http://creativecommons.org/licenses/by/4.0) and the Budapest Open Access Initiative (http://www.budapestopenaccessinitiative.org/read), which permit unrestricted use, distribution, and reproduction in any medium, provided the original work is properly credited.

Tropical Journal of Pharmaceutical Research is indexed by Science Citation Index (SciSearch), Scopus, International Pharmaceutical Abstract, Chemical Abstracts, Embase, Index Copernicus, EBSCO, African Index Medicus, JournalSeek, Journal Citation Reports/Science Edition, Directory of Open Access Journals (DOAJ), African Journal Online, Bioline International, Open-J-Gate and Pharmacy Abstracts

\section{INTRODUCTION}

Lung cancer is a leading cause of mortality among various types of cancers globally, notwithstanding huge advancement in chemotherapy and diagnostic techniques [1]. Non-small cell lung cancer (NSCLC), the primary type of lung carcinoma, is diagnosed in $85 \%$ of patients, whereas small cell lung cancer (SCLC) accounts for about $15 \%$ of lung cancer 
cases [2]. The 5-year survival of patients with NSCLC is still very low (15\%), despite the use of radiation and chemotherapy [3]. Chemotherapeutic compounds generally exert their anticancer effects through activation of apoptosis. Tumour necrosis factor-related apoptosis inducing ligand (TRAIL) is a member of the super-family of tumour necrosis factors. Studies have revealed that TRAIL specifically targets carcinoma cell growth via activation of apoptosis without reduction of normal cell viability [4].

It has been demonstrated that TRAIL exerts its effect by interacting with DR4 and DR5 death receptors in the membrane via ligands attached to it [5]. In addition, TRAIL influences the activities of decoy receptor (DcR)-1, DcR2 and the receptor protein osteoprotegerin [6]. The interaction amongst TRAIL, DR4 and DR5 links to Fas-associated death domain results in activation of caspases, leading to apoptosis [7]. The selectivity of TRAIL in inducing carcinoma cell apoptosis makes it a preferred anticancer candidate in cancer therapy. Unfortunately, some carcinoma cells have developed resistance to the apoptotic effect of TRAIL via different mechanisms [8]. Studies have revealed down-regulated DR4 and DR5 expressions and enhanced decoy receptor levels in carcinoma cells resistant to TRAIL [8, 9]. The level of FLICE-like inhibitory protein [cFLIP $(\mathrm{L})]$ and suppressors of apoptosis are up-regulated in tumor cells resistant to TRAIL [10].

Compounds isolated from plants sensitize carcinoma cells to TRAIL-mediated apoptosis $[11,12]$. Paeonol is a low molecular weight compound obtained from Cortex Moutan, a Chinese herbal plant [13]. The plant is known for its anti-inflammatory properties, and it is used to treat allergies and cancer in traditional Chinese medicine [13]. Many of the drugs prescribed for psoriasis, dermatitis and skin diseases in China contain paeonol as bioactive compound [14]. The present study investigated the lung cancer-sensitizing potential of paeonol to TRAIL treatment.

\section{EXPERIMENTAL}

\section{Cell lines}

The H1975 and BGC823 cells were provided by Chinese Academy of Sciences (Shanghai, China). The cells were kept in RPMI-1640 medium containing $10 \%$ FBS and $100 \mathrm{U} / \mathrm{mL}$ penicillin and streptomycin.

\section{Cell viability assay}

The viability of $\mathrm{H} 1975$ and BGC823 cells following paeonol exposure was determined with 3-(4,5-dimethylthiazol-2-yl)2,5-

diphenyltetrazolium bromide (MTT) assay. The cells were plated in 96-well plates in RPMI-1640 medium, each at a density of $0.5 \times 10^{6}$ cells per well and incubated for $24 \mathrm{~h}$. Thereafter, the medium was replaced with fresh medium containing $1,2,4$ and $8 \mu \mathrm{M}$ paeonol or TRAIL (25 ng/mL) or paeonol ( $8 \mu \mathrm{M})$ plus TRAIL (25 $\mathrm{ng} / \mathrm{mL})$, and cell incubation was continued for 72 h. The 72-h treatment of cells was followed by addition of $20 \mu \mathrm{L}$ MTT. After incubation for $4 \mathrm{~h}$, the medium was removed and DMSO $(150 \mu \mathrm{L})$ was added to the plates so as to solubilize the resultant formazan crystals. Then, the absorbance of each well was read at $490 \mathrm{~nm}$ in a microplate reader.

\section{Annexin V-FITC/PI double staining for detection of apoptosis}

Apoptosis of $\mathrm{H} 1975$ and BGC823 cells was analysed with a flow cytometer using Annexin V-FITC/PI kit. The cells were incubated for $72 \mathrm{~h}$ in medium containing $8 \mu \mathrm{M}$ paeonol or TRAIL (25 $\mathrm{ng} / \mathrm{mL})$ or paeonol $(8 \mu \mathrm{M})$ plus TRAIL (25 $\mathrm{ng} / \mathrm{mL})$. Cell harvesting was followed by PBS washing (two times) and adjustment of the cells to a density of $2 \times 10^{6}$ cells per $\mathrm{ml}$ in $1 \mathrm{X}$ binding buffer. Then, the cells were subjected to staining for 20 min with Annexin V-FITC and PI solution in the dark. Flow cytometer (Beckman Coulter, Inc., Brea, CA, USA) was used for examination of apoptotic cells.

\section{Determination of effect of paeonol on expressions of DR4 and DR5}

The expressions of DR4 and DR5 in H1975 and BGC823 cells after paeonol treatment were assayed using flow cytometry [15]. The cells were treated with $8 \mu \mathrm{M}$ paeonol for $72 \mathrm{~h}$ and then incubated for $50 \mathrm{~min}$ at $4{ }^{\circ} \mathrm{C}$. The antibodies used were monoclonal mouse anti-bodies against DR4 and DR5.

\section{Reverse transcription polymerase chain reaction (RT-PCR) assay}

The cells were incubated for $72 \mathrm{~h}$ with $8 \mu \mathrm{M}$ paeonol, or with DMSO as control. Total RNA was extracted from H1975 and BGC823 cells using TRIzol reagent (Invitrogen; Thermo Fisher Scientific, Inc.). Then, 1- $\mu$ g RNA samples were used to synthesize of cDNA for $20 \mathrm{~min}$ at $37^{\circ} \mathrm{C}$ employing Primescript RT kit. Roche LightCycler®96 RT-PCR system and SYBR 
Premix EX Taq II were used for RT-PCR assay. The mixture $(20 \mu L)$ used for PCR reaction consisted of SYBR Premix EX Taq II $(10 \mu \mathrm{L})$, forward primer $(0.8 \mu \mathrm{L})$, reverse primer $(0.8 \mu \mathrm{L})$, cDNA $(2 \mu \mathrm{L})$ and sterilized water $(6.4$ $\mu \mathrm{L})$. The mixture was amplified under the following conditions: degeneration for $2 \mathrm{~min}$ at $93{ }^{\circ} \mathrm{C}$, then 40 cycles of denaturation for $5 \mathrm{~s}$ at $93{ }^{\circ} \mathrm{C}$, followed by annealing/extension for $15 \mathrm{~s}$ at $58{ }^{\circ} \mathrm{C}$. The $2^{-\Delta \Delta \mathrm{Cq}}$ method was used for determination of relative mRNA expression levels [16].

\section{Western blotting}

The cells were incubated for $72 \mathrm{~h}$ with $8 \mu \mathrm{M}$ paeonol or DMSO as control and then lysed on ice for $45 \mathrm{~min}$ by incubation with lysis buffer. The buffer consisted of sodium chloride $\left(\begin{array}{ll}5 & M\end{array}\right)$, Nonidet P-40 (10\%), NaVO 4 (0.2 M), EGTA (0.1 $\mathrm{M})$, EDTA (0.5 M), phenylmethylsulfonyl fluoride $(0.1 \mathrm{M}), \mathrm{NaF}(1 \mathrm{M})$, HEPES (1 M), aprotinin (2 $\mu \mathrm{g} / \mathrm{mL})$ and leupeptin $(2 \mu \mathrm{g} / \mathrm{mL})$. The lysate was centrifuged to obtain supernatant and BCA assay kit was used to determine the protein content. The proteins were subjected to SDS-polyacrylamide gel electrophoresis, and transferred to PVDF membranes which were blocked on incubation with $5 \%$ non-fat milk. Then, the membranes were incubated at $4^{\circ} \mathrm{C}$ overnight with primary antibodies against JNK, ERK1/2, p38, Bcl-xL, Bcl-2, survivin, Bax, cFLIP, CHOP, xIAP, caspase-3, caspase-8, caspase-9, DcR1, DcR2, DR4 and DR5 (Cell Signaling Technology, Danvers, MA, USA). Thereafter, the membrane was incubated for $1 \mathrm{~h}$ at room temperature with horseradish peroxidase-conjugated goat anti-rabbit secondary antibody. Band visualization was made using ECL detection system (Pierce; Thermo Fisher Scientific, Inc.).

\section{Measurement of ROS}

The H1975 and BGC823 cells were incubated for $72 \mathrm{~h}$ with $8 \mu \mathrm{M}$ paeonol or with DMSO (control), followed by incubation at $37^{\circ} \mathrm{C}$ for 20 min with DCF-DA $(20 \mu \mathrm{M})$. The level of ROS generated was analysed flow cytometrically at $530 \mathrm{~nm}$.

\section{Statistical analysis}

Data are expressed as mean \pm standard deviation (SD). One-way ANOVA and Student's t-test were used for statistical analyses which were carried out with GraphPad Prism 6 software (GraphPad Software, Inc., La Jolla, CA, USA). Differences were taken as statistically significant at $p<0.05$.

\section{RESULTS}

\section{Paeonol and TRAIL inhibited the viability of lung cancer cells}

As shown in Figure 1, paeonol at doses of 1, 2, 4 and $8 \mu \mathrm{M}$ significantly reduced the proliferation of $\mathrm{H} 1975$ and BGC823 cells at $72 \mathrm{~h}$, relative to control $((p<0.05)$. In H1975 cells, viability was reduced to $84,69,49$ and $37 \%$, respectively, on treatment with paeonol at doses of 1, 2, 4 and 8 $\mu \mathrm{M}$, respectively, relative to $100 \%$ in control. Treatment with 1, 2, 4 and $8 \mu \mathrm{M}$ paeonol suppressed BGC823 cell viability to $89,71,53$ and $39 \%$, respectively, relative to $99 \%$ in control. However, combination treatment with paeonol $(8 \mu \mathrm{M})$ and TRAIL $(25 \mathrm{ng} / \mathrm{mL})$ resulted in suppression of the proliferation of $\mathrm{H} 1975$ and BGC823 cells to 21 and $24 \%$, respectively.

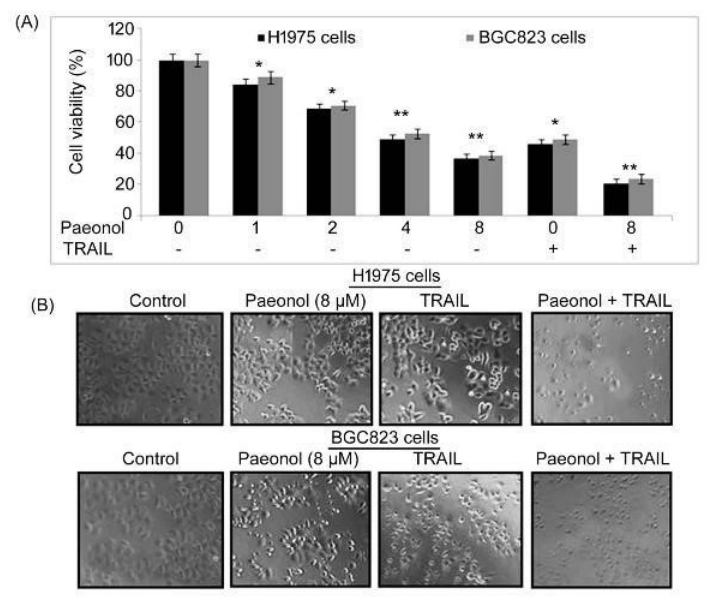

Figure 1: Inhibitory effect of paeonol on viability of H1975 and BGC823 cells. (A) Paeonol treatment for $72 \mathrm{~h}$ was followed by determination of viability using MTT assay. ${ }^{*} P<0.05 ;{ }^{* *} p<0.02$, vs. H1975 control and BGC823 control cells, respectively. (B) Images of cells treated with $8 \mu \mathrm{M}$ paeonol, TRAIL and paeonol plus TRAIL, as seen under a microscope (x200). MTT:

3-(4,5-dimethylthiazol-2-yl)-2,5-diphenytetrazolium bromide

\section{Paeonol promoted TRAIL-induced apoptosis of lung cancer cells}

Following treatment of $\mathrm{H} 1975$ and BGC823 cells with paeonol $(8 \mu \mathrm{M})$, TRAIL $(25 \mathrm{ng} / \mathrm{mL})$ and combination of paeonol and TRAIL, cell apoptosis was analyzed using Annexin V-FITC and PI staining assay. As shown in Figure 2, $8 \mu \mathrm{M}$ paeonol treatment induced apoptosis in H1975 and BGC823 cells to levels of 59.27 and $53.42 \%$, respectively. Ttreatment with TRAIL induced apoptosis in 32.81 and $31.76 \%$ of H1975 and BGC823 cells, respectively. 
However, treatment with combination of paeonol and TRAIL increased apoptosis of H1975 and BGC823 cells to 88.43 and $87.21 \%$, respectively.

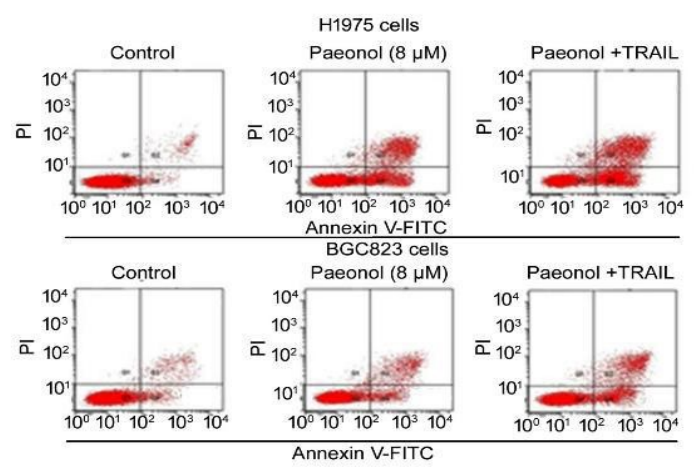

Figure 2: Apoptotic effect of paeonol and TRAIL on lung cancer cells. H1975 and BGC823 cells exposed for $72 \mathrm{~h}$ to paeonol $(8 \mu \mathrm{M})$, TRAIL $(25 \mathrm{ng} / \mathrm{mL})$ and combination of paeonol and TRAIL were analysed for apoptotic changes using Annexin V-FITC and PI staining; ${ }^{*} p<0.05 ;{ }^{* *} p<0.02$, vs. H1975 control and BGC823 control, respectively. TRAIL: tumour necrosis factor-related apoptosis-inducing ligand

Paeonol up-regulated the expressions of DR4 and DR5 and suppressed the expression of decoy receptor

In H1975 and BGC823 cells, the mRNA levels of DR4 and DR5 were significantly increased by treatment with $8 \mu \mathrm{M}$ paeonol treatment, relative to control ( $p<0.05$; Figure $3 \mathrm{~A})$. Moreover, paeonol markedly enhanced the protein levels of DR4 and DR5 in H1975 and BGC823 cells (Figure $3 \mathrm{~B}$ ). In contrast, the levels of DcR1 and DcR2 were suppressed in H1975 and BGC823 cells on treatment with $8 \mu \mathrm{M}$ paeonol (Figure 3 C).

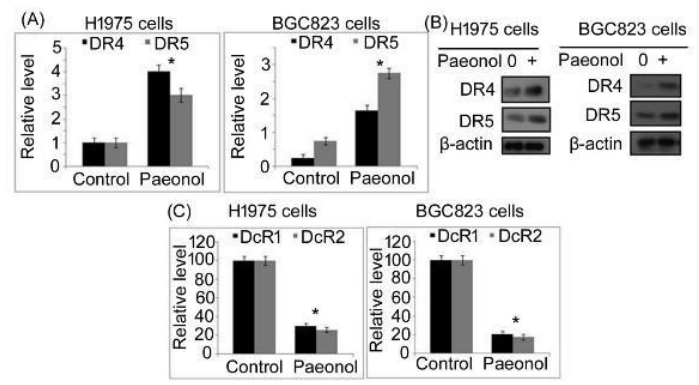

Figure 3: Effect of paeonol on levels of DR4, DR5, DcR1 and DcR2. Levels of DR4 and DR5 in H1975 and BGC823 cells after treatment with $8 \mu \mathrm{M}$ paeonol, as assayed using (A) RT-PCR, and (B) Western blotting. (C) Levels of DcR1 and DcR2 win H1975 and BGC823 cells at $72 \mathrm{~h}$ of treatment with paeonol; ${ }^{*} p<$ 0.05 vs. control cells for $\mathrm{H} 1975$ and BGC823
Paeonol up-regulated CHOP expression in lung cancer cells

Western blotting of $\mathrm{H} 1975$ and BGC823 cells at $72 \mathrm{~h}$ of treatment with $8 \mu \mathrm{M}$ paeonol showed markedly higher CHOP protein expression, relative to the control (Figure $4 \mathrm{~A}$ ). Moreover, RT-PCR data confirmed that paeonol treatment significantly $(p<0.05)$ raised the mRNA expression of CHOP in $\mathrm{H} 1975$ and BGC823 cells (Figure $4 \mathrm{~B}$ ).

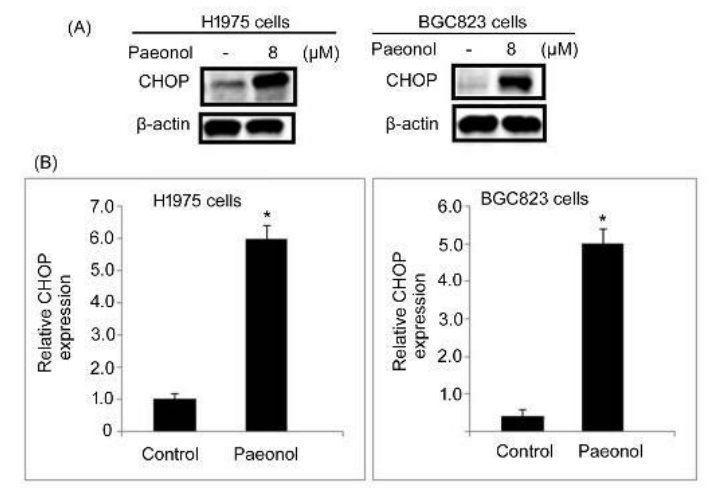

Figure 4: Effect of paeonol on CHOP expressions in H1975 and BGC823 cells. Paeonol-treated H1975 and BGC823 cells were subjected to assay of CHOP expression at $72 \mathrm{~h}$. (A) CHOP protein and (B) CHOP mRNA levels, as assayed using western blotting and RT-PCR assays, respectively; ${ }^{*} p<0.05$ vs. control cells for $\mathrm{H} 1975$ and BGC823

\section{Paeonol suppressed expression of survivin protein and up-regulated expression of pro- apoptotic protein}

The concentrations of survivin, Bcl-2, cFLIP and $\mathrm{Bcl}-\mathrm{xL}$ were elevated in $\mathrm{H} 1975$ and BGC823 cells (Figure 5). However, paeonol significantly decreased the protein levels of survivin, Bcl-2, cFLIP and Bcl-xL in H1975 and BGC823 cells, while it markedly up-regulated the protein levels of caspase-3, caspase- 8 and caspase- 9 , relative to the control (Figure 5). In paeonol-treated H1975 and BGC823 cells, Bax level was also markedly elevated, relative to the control cells.

\section{Paeonol induced ROS generation in lung cancer cells}

Changes in ROS levels in H1975 and BGC823 cells were measured at $72 \mathrm{~h}$ of treatment with 8 $\mu \mathrm{M}$ paeonol (Figure 6). The concentrations of ROS in H1975 and BGC823 cells were significantly elevated, when compared to control, on treatment with paeonol. 


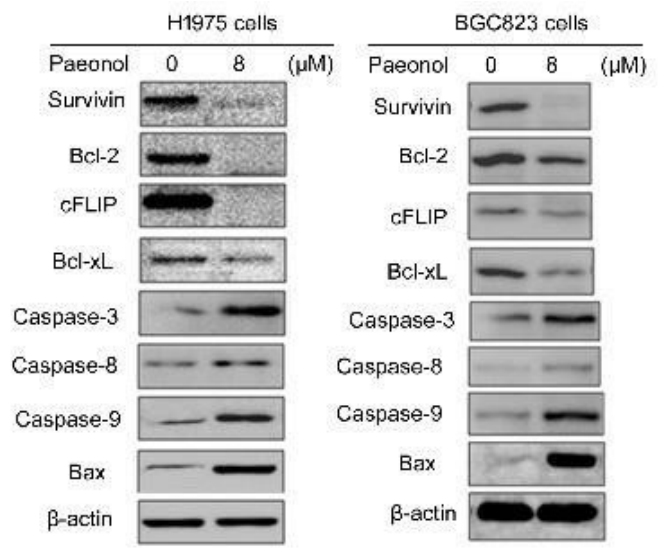

Figure 5: Effect of paeonol on survivin and proapoptotic proteins. Following $72 \mathrm{~h}$ treatment with 8 $\mu \mathrm{M}$ paeonol, survivin and pro-apoptotic protein levels were determined in H1975 and BGC823 cells using western blot assay
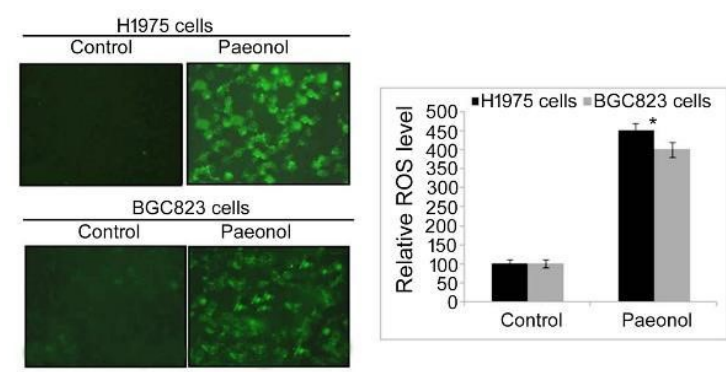

Figure 6: Effect of paeonol on ROS production in lung cancer cells. The $\mathrm{H} 1975$ and BGC823 cells were treated with $8 \mu \mathrm{M}$ paeonol or DMSO (control) for $72 \mathrm{~h}$, followed by determination of ROS levels using flow cytometry

\section{MAPKs mediated tangeretin-induced upregulation of TRAIL receptors}

Treatment with paeonol markedly elevated $p$ ERK and p-JNK in H1975 and BGC823 cells, relative to the control cells (Figure 7). The increases in p-ERK level in H1975 and BGC823 cells on treatment with paeonol were much higher those of $p$-JNK. However, no significant increases in p-p38 expression were observed in H1975 and BGC823 cells on exposure to paeonol.

\section{DISCUSSION}

Although tumor necrosis factor-related apoptosis-inducing ligand (TRAIL) has been found to be effective in cancer therapy, its antitumor potential is limited because of the development of resistance by tumor cells $[7,8]$. Studies have revealed lower levels of death receptors and higher expressions of $\mathrm{Bcl}-2$, survivin and CFLIP in TRAIL-resistant tumor cells $[8,9,15,16]$.

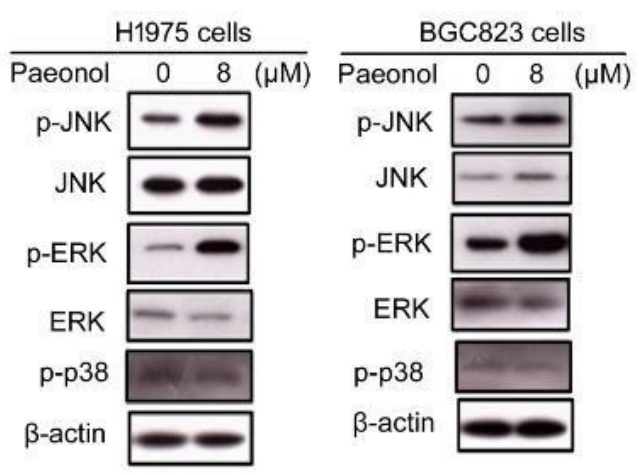

Figure 7: Effect of paeonol on activation of JNK/ERK1/2/p38. JNK/ERK1/2/p38 activation in $\mathrm{H} 1975$ and BGC823 cells was determined at $72 \mathrm{~h}$ of paeonol treatment, using western blotting

The anti-apoptotic protein XIAP is also overexpressed in tumor cells resistant to TRAIL [16]. Therefore, sensitization of tumor cells to TRAIL promotes apoptosis, with tremendous potential for treatment of tumors.

Some molecules sensitize carcinoma cells to TRAIL, thereby efficiently enhancing apoptosis $[11,17]$. It has been reported that XIAP inhibits caspase- 3 , caspase- 7 and caspase- 9 , whereas cFLIP competes for Fas-associated death domain in TRAIL-resistant tumor cells $[9,16]$. In the present study, paeonol exhibited cytotoxic effect on H1975 and BGC823 cells and significantly suppressed their proliferation. Interestingly, the cytotoxic effect produced by combined treatment with paeonol and TRAIL was much higher than that of paeonol or TRAIL when used separately. This provides evidence that paeonol sensitized H1975 and BGC823 cells to the cytotoxic effects of TRAIL.

Findings from MTT assay were consistent with results obtained using Annexin V-FITC and PI assay. Although apoptosis was induced significantly in $\mathrm{H} 1975$ and BGC823 cells on treatment with paeonol or TRAIL, the strongest effect was produced by paeonol/TRAIL combination. Moreover, paeonol targeted expressions of various proteins related to survival of cells i.e., Bcl-2, survivin, cFLIP and XIAP in H1975 and BGC823 cells. Therefore, paeonol sensitized $\mathrm{H} 1975$ and BGC823 cells to TRAIL by suppressing the protein expression of survivin. TRAIL-mediated apoptosis in carcinoma cells is enhanced by some compounds via enhancement of the activities of caspases $[11,18]$.

In general, TRAIL binds to DR4 and DR5 receptors and subsequently activates executor 
caspases thereby inducing apoptosis of carcinoma cells [22]. Death receptors are downregulated in TRAIL-resistant cells, resulting in enhancement of DR4 and DR5, and promotion of apoptosis $[9,18,19]$. Over-expressions of DcR1 and DcR2 have been reported in TRAIL-resistant cells, resulting in resistance to apoptosis [20]. The transcriptional factor, $\mathrm{CHOP}$, on binding to the promoter region of DR5 receptor, upregulates its expression [21].

In the present study, paeonol enhanced the expressions of DR4 and DR5 in H1975 and BGC823 cells, while it downregulated the expressions of DcR1 and DcR2. In addition, there were marked increases in $\mathrm{CHOP}$ level in H1975 and BGC823 cells on treatment with paeonol. Death receptors are induced in carcinoma cells by enhanced production of reactive oxygen species [17]. Moreover, the level of stress-regulated protein, $\mathrm{CHOP}$ is also enhanced by over-production of ROS [21].

Studies have shown that TRAIL-mediated increase in DR5 expression and induction of apoptosis by chemotherapeutic agents occur via ROS over-production [11,22]. During TRAILinduced apoptosis, the levels p-ERK, p-JNK and p-p38 levels are markedly increased via ROS signalling pathway. In the present study, paeonol treatment promoted ROS levels and activated ERK and JNK in H1975 and BGC823 cells. Thus, paeonol sensitized H1975 and BGC823 cells to TRAIL through ROS-mediated activation of the JNK/ERK pathway.

\section{CONCLUSION}

Paeonol inhibits the viability of lung cancer cells via upregulation of death receptors, activation of JNK/ERK-CHOP pathway and generation of ROS. Therefore, paeonol has promising potential as an agent for lung cancer treatment.

\section{DECLARATIONS}

\section{Conflict of interest}

No conflict of interest is associated with this work.

\section{Contribution of authors}

The authors declare that this work was done by the authors named in this article and all liabilities pertaining to claims relating to the content of this article will be borne by them. All the experiments were performed by Yanqing Fan and Xiaoyan Chen under the supervision of Guizhi Zhang.
Xiaoyan Chen collected the data and did statistical analysis. Yanqing Fan did most part of experiments.

\section{Open Access}

This is an Open Access article that uses a funding model which does not charge readers or their institutions for access and distributed under the terms of the Creative Commons Attribution License (http://creativecommons.org/licenses/by/ 4.0) and the Budapest Open Access Initiative (http://www.budapestopenaccessinitiative.org/rea d), which permit unrestricted use, distribution, and reproduction in any medium, provided the original work is properly credited.

\section{REFERENCES}

1. Siegel R, Ma J, Zou Z, Jemal A. Cancer statistics, 2014. CA Cancer J Clin 2014; 64: e9-e29.

2. Herbst RS, Heymach JV, Lippman SM. Lung cancer. $N$ Engl J Med 2008; 359: 1367-1380.

3. Brambilla E, Gazdar A. Pathogenesis of lung cancer signalling pathways: roadmap for therapies. EurRespir J 2009; 33: 1485-1497.

4. Ashkenazi A, Pai RC, Fong S, Leung S, Lawrence DA, Marsters SA, Blackie C, Chang L, McMurtrey AE, Hebert $A$, et al. Safety and antitumor activity of recombinant soluble Apo2 ligand. J Clin Invest 1999; 104: 155-162.

5. Pan G, Ni J, Wei YF, Yu G, Gentz R, Dixit VM. An antagonist decoy receptor and a death domaincontaining receptor for TRAIL. Science 1997; 277: 815818.

6. Emery JG, McDonnell P, Burke MB, Deen KC, Lyn S, Silverman C, Dul E, Appelbaum ER, Eichman C, DiPrinzio $R$, et al. Osteoprotegerin is a receptor for the cytotoxic ligand TRAIL. J Biol Chem 1998; 273: 1436314367.

7. Ashkenazi A, Dixit VM. Death receptors: signaling and modulation. Science 1998; 281: 1305-1308.

8. Zhang L, Fang B. Mechanisms of resistance to TRAILinduced apoptosis in cancer. Cancer Gene Ther 2005; 12: 228-237.

9. Sanlioglu $A D$, Dirice E, Aydin C, Erin N, Koksoy S, Sanlioglu S. Surface TRAIL decoy receptor-4 expression is correlated with TRAIL resistance in MCF7 breast cancer cells. BMC Cancer 2005; 5: 54.

10. Griffith TS, Kucaba TA, O'Donnell MA, Burns J, Benetatos C, McKinlay MA, Condon S, Chunduru S. Sensitization of human bladder tumor cells to TNF related apoptosis-inducing ligand (TRAIL)-induced apoptosis with a small molecule IAP antagonist. Apoptosis 2011; 16: 13-26.

11. Gupta SC, Reuter S, Phromnoi K, Park B, Hema PS, Nair M, Aggarwal BB. Nimbolide sensitizes human colon cancer cells to TRAIL through reactive oxygen species-

Trop J Pharm Res, March 2021; 20(3): 472 
and ERK-dependent up-regulation of death receptors, p53 and Bax. J Biol Chem 2011; 286: 1134-1146.

12. Gupta SC, Francis SK, Nair MS, Mo YY, Aggarwal BB. Azadirone, a limonoidtetranortriterpene, induces death receptors and sensitizes human cancer cells to tumor necrosis factor-related apoptosis-inducing ligand (TRAIL) through a p53 protein-independent mechanism. J Biol Chem 2013; 288: 32343-32356.

13. Liu MH, Lin AH, Lee HF, Ko HK, Lee TS and Kou YR: Paeonol attenuates cigarette smoke-induced lung inflammation by inhibiting ROS-sensitive inflammatory signaling. Mediators Inflamm 2014: 651890, 2014.

14. Chou TC: Anti-inflammatory and analgesic effects of paeonol in carrageenan-evoked thermal hyperalgesia. Br J Pharmacol 139: 1146-1152, 2003.

15. Chawla-Sarkar M, Bae SI, Reu FJ, Jacobs BS, Lindner $D J$, Borden EC. Down-regulation of Bcl-2, FLIP or IAPs (XIAP and survivin) by siRNAs sensitizes resistant melanoma cells to Apo2L/TRAIL-induced apoptosis. Cell Death Differ 2004; 11: 915-923.

16. Deveraux QL, Takahashi R, Salvesen GS, Reed JC. Xlinked IAP is a direct inhibitor of cell-death proteases. Nature 1997; 388: 300-304.

17. Prasad S, Yadav VR, Kannappan R, Aggarwal BB. Ursolic Acid, a pentacyclintriterpene, potentiates TRAILinduced apoptosis through p53-independent upregulation of death receptors evidence for the role of reactive oxygen species and JNK. J Biol Chem 2011; 286: 5546-5557.

18. Moon DO, Park SY, Choi YH, Ahn JS, Kim GY. Guggulsterone sensitizes hepatoma cells to TRAILinduced apoptosis through the induction of CHOPdependent DR5: Involvement of ROS-dependent ERstress. Biochem Pharmacol 2011; 82: 1641-1650.

19. Fisher MJ, Virmani AK, Wu L, Aplenc R, Harper JC, Powell SM, Rebbeck TR, Sidransky D, Gazdar AF, El Deiry WS. Nucleotide substitution in the ectodomain of trail receptor DR4 is associated with lung cancer and head and neck cancer. Clin Cancer Res 2001; 7: 16881697.

20. Mellier G, Huang S, Shenoy K, Pervaiz S. TRAILing death in cancer. Mol Aspects Med 2010; 31: 93-112.

21. Lin N, Sato T, Takayama Y, Mimaki Y, Sashida Y, Yano $M$, Ito A. Novel anti-inflammatory actions of nobiletin, a citrus polymethoxy flavonoid, on human synovial fibroblasts and mouse macrophages. Biochem Pharmacol 2003; 65: 2065-2071.

22. Sung B, Ravindran J, Prasad S, Pandey MK, Aggarwal $B B$. Gossypol induces death receptor-5 through activation of the ROS-ERK-CHOP pathway and sensitizes colon cancer cells to TRAIL. J Biol Chem 2010; 285: 35418-35427. 